Журнал«Герстективита інновації наукиљ

(Серія«Гедагогіка», Серія«Гцихологія», Серія«Медицинв»

№(6) 2022

УДК- 37.091.12:005.963

https://doi.org/10.52058/2786-4952-2022-1(6)-164-172

Дікова-Фаворська Олена Михайлівна доктор соціологічних наук, професор, професор кафедри суспільно-гуманітарних наук, КЗ "Житомирський обласний інститут післядипломної педагогічної освіти Житомирської обласної ради", вул. Михайлівська, 15, Житомир, 10014, https://orcid.org/0000-0002-1600-6875

\title{
ТРАНСФОРМУВАННЯ МОДЕЛИ ПІДВИЩЕННЯ КВАЛІФІКАЦІЇ ПЕДАГОГІЧНИХ ПРАЦІВНИКІВ ЯК ВІДПОВІДЬ НА ВИКЛИК ПАНДЕМІї
}

Анотація. В представленій статті акцентовано увагу на оновлених вимогах щодо професійних стандартів педагогічних працівників, що зумовлені процесами реформування освіти. В цьому контексті освіта дорослих трансформує свою модель, яка з формату традиційної траєкторії переходить у формат багатовекторності. Освіта впродовж життя надає можливості поглиблювати, модернізувати отримані знання та опановувати новим контентом відповідно до актуальних запитів. Сучасна ситуація , що пов'язана 3 викликами пандемії COVID-19 окреслила суттєві проблеми у професійній підготовці фахівців, що потребують швидкого реагування та розробки освітніх пропозицій в системі підвищення кваліфікації фахівців, зокрема в галузі освіти. Окреслено сучасні вимоги до професійного потенціалу сучасного фахівця, зокрема до soft skills. Наголошено на широті можливостей у підготовці та реалізації професійної стратегії фахівця. Акцент здійснено на ролі інституту післядипломної педагогічної освіти у забезпеченні професійного оновлення базових знань вчителів-слухачів курсів та модернізації їх змісту. У роботі представлено матеріали власного дослідження, що дозволило побудувати модель підвищення кваліфікації педагогічних працівників регіону з урахуванням нормативної складової та запитів слухачів, що сформувалися в ситуації епідеміологічних ризиків та невизначеності.

Ключові слова: освіта дорослих, вимоги до професійної підготовки вчителя, якість освіти, пандемія, підвищення кваліфікації педагогів, дистанційне навчання.

Dikova-Favorska Olena Mykhailivna Dr Habil. (Sociology), Professor, Department of Social Sciences and Humanities, Zhytomyr Regional Institute of Postgraduate Pedagogical Education, Mykhailivska St., 15, Zhytomyr, 10014, https://orcid.org/0000-0002-1600-6875 


\title{
TRANSFORMING THE ADVANCED TRAINING MODEL FOR PEDAGOGICAL WORKERS AS A RESPONSE TO THE PANDEMIC CHALLENGE
}

\begin{abstract}
The presented article focuses on the updated requirements for professional standards of teachers due to the processes of education reform. Adult education is transforming from a traditional trajectory format to a multi-vector format in this context. Lifelong learning provides opportunities to deepen, modernize the acquired knowledge and master new content following current needs. The current situation caused by the challenges of the COVID-19 pandemic has outlined significant problems in the training of specialists who need to respond quickly and develop educational proposals in the professional development system in the field of education. The author outlines modern requirements to the professional potential of a modern specialist, particularly soft skills. Emphasis is placed on the breadth of opportunities to prepare and implement the specialist's professional strategy. Emphasis is placed on the role of the institute of postgraduate pedagogical education in providing a professional update of basic knowledge of teachers-students and on modernization of their content. The paper presents our research materials, which allowed us to build a model of teachers' professional development in the region, considering the regulatory component and the demands of students formed in a situation of epidemiological risks and uncertainty.
\end{abstract}

Keywords: Adult education, teacher training requirements, quality of education, pandemic, teacher training, distance learning.

Постановка проблеми. В умовах реформування сучасної освіти та створення умов для розвитку мобільної, креативної, конкурентоздатної особистості, яка постійно саморозвивається є стрижневою складовою в організації підготовки фахівця. До педагога, як головного учасника модернізаційних змін в освіті, висуваються високі вимоги. Професійні стандарти педагогічних працівників вимагають від сучасного педагога універсальної освіченості, максимальної інформованості (компетентності), ерудиції, прогресивності (креативності), гнучкості у підходах, бездоганного зовнішнього вигляду, здатності адаптуватися до нестандартних рішень, постійного професійного розвитку $[1,2]$. Сучасні європейські документи також диктують значимість неперервного особистісного розвитку педагога, розвитку особистісних цінностей, підтримку ключових та універсальних компетентностей $[3,4]$.

Донесення знань 3 використанням сучасних форм та технологій - це один аспект процесу, інший - формування у суб'єктів навчального процесу soft skills, що передбачає формування:

- здатності працювати з людьми, сприймати нові ідеї та іншу думку;

- вміння розбирати професійні завдання;

- аналізувати причини та наслідки; 
Журнал«Герстективита інновації наукиљ

(Серія «Гедагогіка», Серія «Гиихологія», Серія «Медицинв»

№(6) 2022

- вміння виокремлювати головне від вторинного;

- готовності до змін, зокрема в освітній галузі.

Аналіз останніх досліджень і публікацій. Активно займають свої позиції представники (спеціалісти) нових модерних професій, таких як координатори освітніх онлайн-платформ, модератори навчальних процесів, ментори стартапів тощо.

Виклад основного матеріалу. Освіта, зокрема освіта дорослих, тобто тих, хто бажає продовжувати навчатися, здобувати нові, сучасні професії, та тих, хто відчуває необхідність у постійному оновленні професійних знань через самоосвіту, формальні та неформальні активності у підвищенні кваліфікації, потребує оновлення змісту та пошуку нового. Це підтверджує тезу, що освіта 3 формату традиційної траєкторії, де людина отримувала одну освіту по завершенню школи, переходить у формат багатовекторності.

Спостерігається тенденція здобуття набору спеціальностей однією особою, що надає можливість їй набути певної універсальності, гнучкості, і це, в свою чергу, зміцнює позицію у певній професійній групі, створює умови для побудови кар'єри, а у разі необхідності, надає можливості здійснити власний стартап, спираючись на набутий досвід та осучаснені знання.

Освіта впродовж життя (lifelong learning) - ознака сучасного суспільства, частина професійної культури спеціаліста, зокрема в галузі освіти. Усвідомлення думки, що налаштування на зміни є однією з умов професійної та особистісної самореалізації. Неперервна освіта розглядається як об'єднання знань, що необхідні базовій освіті, як навчання , наближене до реалій життя.

Ключовим завданням в умовах криз та невизначеності $є$ забезпечення якості освіти, в цілому, та освітнього процесу зокрема. Якість стає керівною ідеєю закладів освіти та розглядається як суттєва складова освітньої політики. Це пов'язано з реалізацією цілей та принципів сталого розвитку суспільства, заснованих на задоволенні запитів споживачів у покращенні якості життя, як однієї з основних складових якого є якість в сфері освіти. Якість освіти - це комплексний показник співвідношення мети і результатів навчання, ступеня задоволеності очікувань учасників освітнього процесу від наданих освітніх послуг, а також рівня сформованості компетентностей у тих, хто навчається.

Формуючи професійні компетентності необхідно будувати наскрізні компетентності, що високо цінуються роботодавцями. Саме вони дають можливість фахівцю, незалежно від набутої професії, більш ефективно реалізувати себе на ринку праці, швидко адаптуватися до динамічних змін, критично усвідомлювати отриманні дані та опановувати нові види діяльності. Визнання важливості “наскрізних" або “ключових" компетентностей призвело до переосмислення набору вимог, що висуваються працівнику, зокрема педагогічному.

Сьогодні людина має широкі можливості щодо побудови власної професійної стратегії як через формальну, так і через неформальну освіту. Формальна освіта- безперервний процес навчання 3 набуття професійних 
компетентностей дорослих, які навчаються в закладах освіти, що пройшли державну реєстрацію. Неформальна освіта - освітній процес, що відбувається поза організації формальної освіти, але пропонує отримання документа державного зразка та забезпечує необхідним потенціалом мобільно адаптуватися до різних просторових та часових умов відповідно до запитів аудиторій різних вікових груп, з орієнтацією на загальні та особистісні потреби задля адаптації до мінливих умов життя, а також для творчої самореалізації. Інформальна освіта неорганізована, позбавлена основних характеристик дидактично (форми і методи освіти) організаційного процесу (в родині, на робочому місці, в неформальних об’єднаннях, соціальних групах тощо).

Додаткова освіта дорослих має два шляхи:

- Перший - отримання другої, іншої освіти, навчання в аспірантурі (докторантурі);

- Другій - проходження курсів підвищення кваліфікації.

Перепідготовка - це вид додаткової освіти (альтернатива другій/іншій освіті). Саме проходження курсів підвищення кваліфікації дозволяють працювати в закладах освіти спеціалістам - інженерам, економістам, медикам, які бажають долучитися до певного профілю педагогіки, що $є$ суміжним базовій професії.

Соціальна ситуація в світі, що знаходиться в стані розбалансованості, економічної нестабільності та глобального стресу, пов'язана 3 поширенням нового небезпечного вірусу, змусила уряди країн вживати заходи епідеміологічної безпеки, зокрема забезпечення соціальної ізоляції, що стало чи не єдиним ефективним засобом протидії поширенню хвороби планетою.

Системи освіти у всьому світі змушені стрімко вживати заходів реагування та адаптації. Уряди країн оперативно здійснювали кроки для забезпечення неперервної освіти та безпеки всіх суб'єктів навчального процесу, здійснюючи перехід на віддалене навчання в дистанційномусинхронному та асинхронному форматі та організацією за державний кошт онлайн (телевізійних) шкіл тощо.

Раптовий перехід на новий формат навчання виявив низку проблем, зокрема таких як:

- відсутність швидкісного інтернету, особливо в місцях сільської місцевості, що не дозволило системно організувати передбачений онлайн процес навчання;

- низький показник забезпечення сучасними гаджетами всіх членів родини, і тих, хто навчається, і тих, працює віддалено;

- невідповідний рівень цифрової грамотності серед учнів та, що особливо непередбачено, вчителів.

Обумовлена COVID-19 криза продемонструвала, що система підготовки вчителів як на етапі першочергового здобуття освіти, так i в системі підвищення кваліфікації потребує реформування з метою більш ефективного розвитку у вчителів навичок використання нових засобів викладання. 
Журнал«Герспективитаінновації наукиљ

(Серія «Гедагогіка», Серія«ГЕихологія», Серія«Медицина»

№1(6) 2022

Зміцнення потенціалу педагогічної практики через оновлення програм перепідготовки та підвищення кваліфікації дозволить витримати та гідно відповісти на виклик сьогодення. Освітні втрати, що пов'язані з тривалим розбалансуванням навчального процесу, ставлять під загрозу численні досягнення в сфері освіти. Світ вже не буде таким як раніше, тому системи освіти маємо будувати на засадах гнучкості, мобільності, доступності та інклюзивності.

3 метою оцінки якості освітніх послуг, що надаються Житомирським інститутом післядипломної педагогічної освіти на курсах підвищення кваліфікації педагогічних працівників у листопаді 2020 р. проведено зондажне дослідження, в якому за суцільною вибіркою було опитано 1279 слухачів.

Об'єктом дослідження виступала організація навчального процесу на курсах підвищення кваліфікації педагогічних працівників (регіональне замовлення). Предметом - визначення запитів слухачів на нові теми для формування навчальних планів на 2021 р. У фокусі дослідження було:

- визначення за рейтингом практично-орієнтованих тем та тем, що формують уяву про явище , технологію, систему;

- окреслення тем, що потребують поглиблення або кардинальної зміни;

- оиінка якості матеріалів, що розміщені на платформі для самостійного опрацювання, та презентацій лекцій, які супроводжують лекції викладачів.

Результати опитування респондентів свідчать про високий рівень задоволеності організацією навчання в умовах пандемії $(92 \%$ повністю задоволені, $5,9 \%$ частково задоволені, $0,7 \%$ частково незадоволені). Представлені матеріали, що доповнюють лекції викладачів теж отримали високу оцінку (89,3\% повністю задовольнили, 9,9\% - частково задовольнили, $0,8 \%$ - частково не задовольнили).

Дослідницькій команді Житомирського інституту післядипломної педагогічної освіти вдалося окреслити запити слухачів курсів підвищення кваліфікації щодо оновлення навчальних планів в ситуації змін та невизначеності.

Так, першою позицією окреслено тему "Дистанційне навчання", респонденти одностайно наголошують на необхідності вдосконалення та поглиблення знань 3 методології організації дистанційного навчання, удосконалення методик викладання з використанням цифрових технологій, опанування освітніми платформами для забезпечення сучасного навчального процесу, оволодіння інструментами, що дозволить надати належну якість викладанню, підвищить мотивацію учнів, розширить можливості вчителів в умовах карантинних обмежень.

Наступною, за рейтингом, була названа тема "COVID-19". Респонденти усвідомлюють новизну ситуації, що склалася, недостатність інформації, іiі непереконливість та суперечливість, тому висловлюють побажання у підготовці теми, яка б не тільки пояснювала особливості сучасного стану, а й надавала певний алгоритм роботи з учнями та їх батьками через усвідомлення 
кризи як ситуації невизначеності 3 характеристиками викликів, що формуються, та пропонувала би алгоритм дій на період дистанційного або змішаного навчання.

Навантаження, викликане новими умовами професійної діяльності, призвело до певного стану психологічного виснаження, емоційного та професійного вигорання, що потребує корекції. Тому логічною була пропозиція щодо посилення психологічного супроводу навчального процесу, ознайомлення 3 методиками та техніками превентизації вигорання як для педагогічних працівників так і для учнів, які опинилися в ситуації обмеженого міжособистісного спілкування, що призвело до певного психологічного дискомфорту.

Неординарність нової соціальної ситуації обумовила формування нового запиту щодо посилення взаємодії трикутника "школа-батьки-діти" в зв'язку 3 поглибленням напруження та проявів агресії у дітей та емоційної втоми у батьків під час роботи у віддаленому форматі. Вчителі усвідомлюють, що збільшення обсягів домашнього навчання, зростання відповідальності та навантаження батьків у забезпеченні якості навчання потребують нових підходів, в тому числі і методичної підтримки учнівських родин.

Безумовно, традиційним запитом на курсах підвищення кваліфікації залишається запит на нові методики та успішні практики в навчальному процесі. Ситуація, що склалася, потребує швидкого реагування на переформатування, тому доцільно вивчати світовий досвід організації навчального процесу під час карантинних обмежень та запроваджувати кращі практики в навчальний процес українських закладів освіти.

Окремою позицією визначено особливості організації інклюзивного навчання в період карантину. Саме ця категорія дітей опинилася у найкритичнішому стані, під загрозою також і ті досягнення, які формувалися повільно кропіткою роботою командою інклюзивного класу. Нові умови, зокрема викладання онлайн та ТВшкола, а в більшості випадків відсутність безпосередньої структурованої роботи 3 учнем, який має особливі освітні потреби, поглиблює проблемну ситуацію 3 організації інклюзивного навчання в цілому.

Новим запитом у формуванні навчального плану на 2021 рік була пропозиція введення теми "Алгоритм роботи з учнями в позаурочний час у віддаленому режимі". Послаблення позитивної складової, порушення комунікаційних практик поглиблюють ситуацію психологічного дискомфорту в учнів, і це потребує вивчення та вирішення через розробку та впровадження нових форм роботи з використанням цифрових технологій і не тільки.

Результати опитування дозволили здійснити узагальнення та визначити, що залишається актуальним, які теми потребують розширення та поглиблення та, що необхідно ввести до навчальних планів відповідно до нових запитів слухачів курсів.

Таким чином, нам вдалося побудувати модель підвищення кваліфікації на 2021/2022 навчальний рік, що має стати роком подолання викликів, роком стабільності та системності в освіті. 
Журнал«Герспективита іноваціїнауки

(Серія «Гедагогіка», Серія «Геихологія», Серія «Медицив»

№1(6) 2022

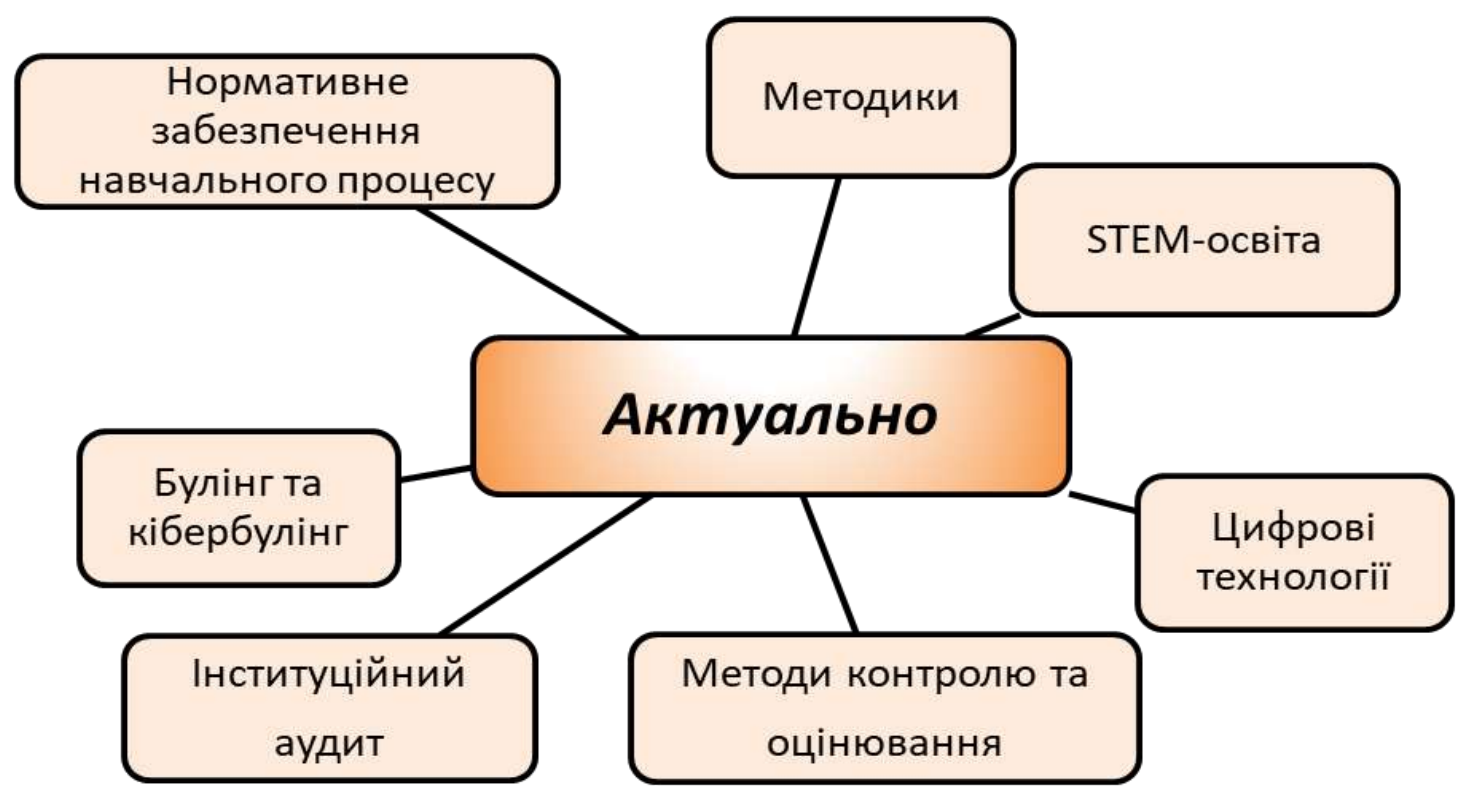

Рис. 1. Актуальні теми підвищення кваліфікації педагогічних пращівників

На рис. 1 представлено теми, які залишаються найзатребуванішими серед слухачів курсів підвищення кваліфікації. Безумовно, їх вибір обумовлено як об'єктивною, так і суб'єктивною складовою, що пов'язана з особистістю викладача, який викладає ту чи іншу тему. Як бачимо, актуальними залишаються цифрові технології, що виступають основою в організації дистанційного навчання, STEMосвіта, модерні методики, а також теми булінгу та кібербулінгу, що викликають занепокоєння професійної спільноти у своєму поширенні та різноманітності загрозливих та небезпечних форм. Затребуваними залишаються теми нормативного забезпечення навчального процесу, методів контролю та інституційного аудиту. Саме поширення нової форми перевірки діяльності закладів середньої освіти пояснює затребуваність означеної теми.

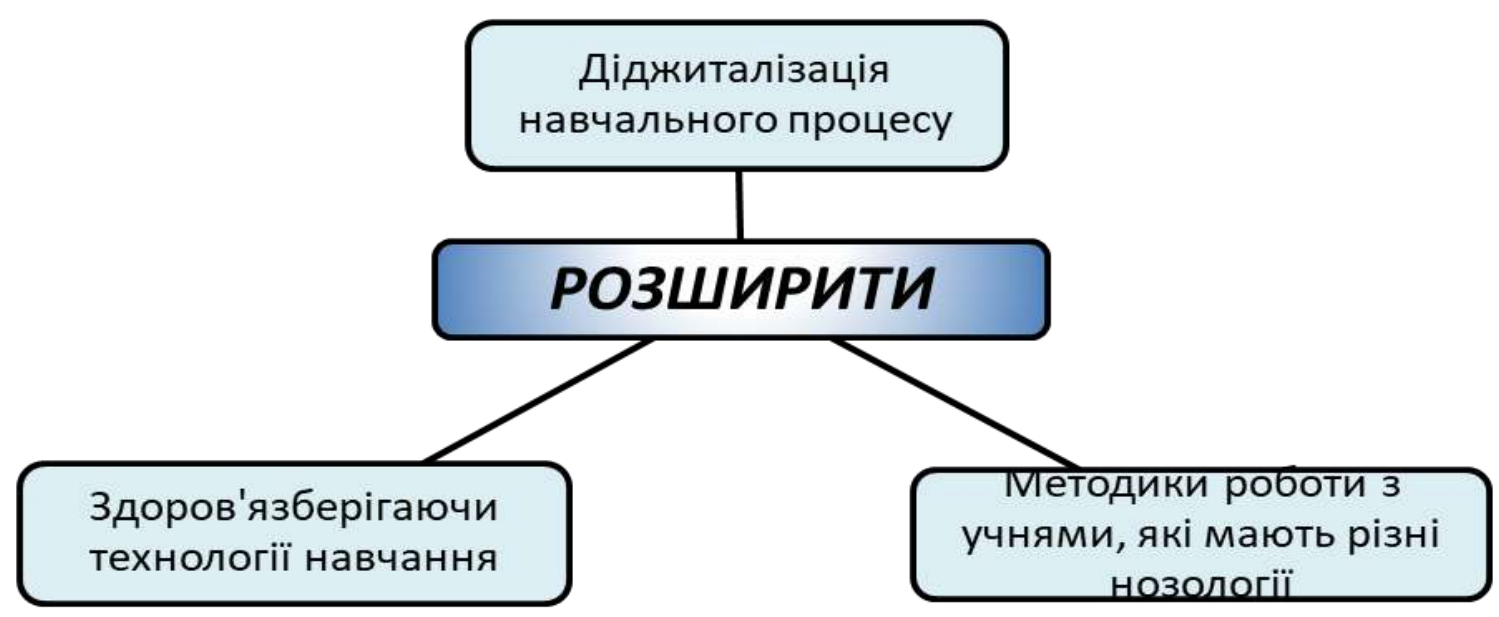

Pис. 2. Теми, щуо потребують розширення у системі підвищення кваліфікаиії педагогічних працівників 
Як бачимо, поглиблення потребують теми, які набули нового звучання в ситуації епідеміологічних обмежень. Це, в першу чергу, діджиталізація навчального процесу, про яку мова велась вище, це - здоров'язберігаючи технології навчання, що потребують оновлення, глибини та багатовекторності, це - методики роботи з учнями, які мають різні нозології (хвороби), що дозволить змінити на краще ситуацію в організації інклюзивного навчання.

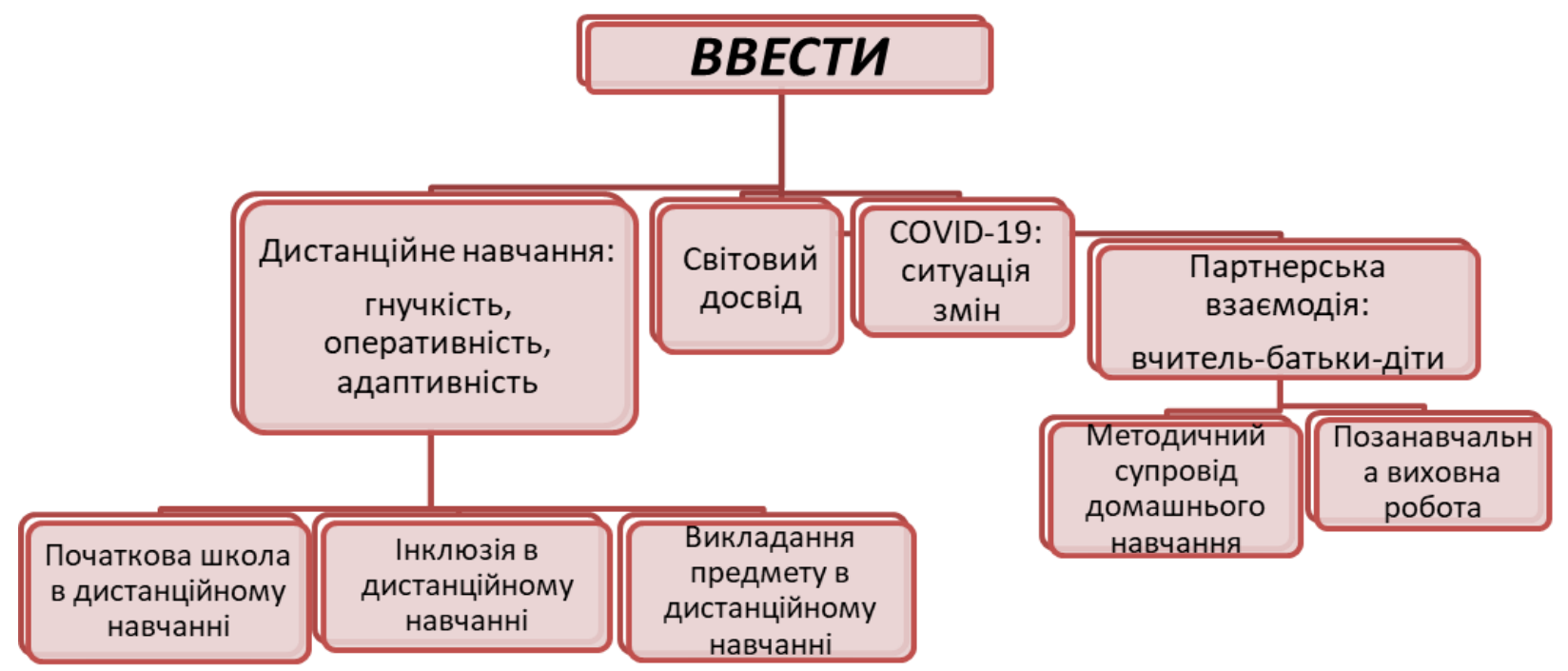

Puс. 3. Теми, що потребують запровадження у системі підвищення кваліфікачії педагогічних працівників

Орієнтуючись на запити педагогічних працівників, які проходять підвищення кваліфікації на базі Інституту післядипломної педагогічної освіти до нових навчальних планів бажано ввести чотири тематичних блоки:

- дистанційне навчання, де залежно від категорій слухачів, запропонувати теми з "Початкова школа в дистанційному навчанні", "Інклюзія в дистанційному форматі" та викладання окремих предметів з використанням цифрових технологій в режимі дистанційного навчання;

- світовий досвід. Тема передбачає як розкриття особливостей організації навчання під час пандемії, так і знайомство 3 успішними практиками викладання окремих предметів та реалізацій нових освітніх концепцій таких як наскрізне викладання та інклюзія;

- COVID-19 - ситуація змін. Структура лекції передбачає не тільки окреслення ситуації, що склалася з поширенням нового агресивного вірусу, а й містить пропозицію щодо алгоритму дій по збереженню психічного та емоційного здоров'я всіх учасників навчального процесу.

- партнерська взаємодія - вчитель-батьки-учні, яка передбачає оптимізацію командної роботи задля упередження соціальних ризиків в дитячому середовищі, задоволення потреби на позитивну емоцію та формування засад соціальної солідарності. 
Висновки. Отже, представлена модель, яка враховує нормативні вимоги та нагальні запити споживачів освітніх послуг, дозволяє забезпечити оновлення професійної діяльності педагогічного працівника, озброїти необхідними інструментами для проведення сучасного уроку в нових умовах, сформувати уяву щодо особливостей викликів, пов'язаних 3 поширенням небезпечного вірусу, підготувати до протидії небезпечних проявів в дитячому середовищі, ознайомити 3 техніками самодопомоги з попередженням емоційного та професійного вигорання. Безумовно, системна підготовка педагогічних працівників, їх підтримка на рівні держави та місцевих громад в ситуації сьогодення набуває особливого значення та глибини. Довготривалі рішення мають грунтуватися з урахуванням отриманого досвіду, аналізу слабких позицій, що були виявлені в ситуації професійного стресу під час пандемії, та на основі широкого впровадження технологій для забезпечення неперервності освіти.

\section{Лimepamypa:}

1. Про затвердження професійного стандарту «Практичний психолог закладу освіти» : Наказ Міністерства економіки України від 24.11.2020 № 2425 - Режим доступу: https://mon.gov.ua/ua/news/zatverdzheno-profesijnij-standart-praktichnij-psiholog-zakladu-osviti

2. Про затвердження професійного стандарту за професіями "Вчитель початкових класів закладу загальної середньої освіти", "Вчитель закладу загальної середньої освіти","Вчитель 3 початкової освіти (з дипломом молодшого спеціаліста)" : Наказ Міністерства розвитку економіки, торгівлі та сільського господарства від 23.12 .2020 р. №2736. - Режим доступу: https://rada.info/upload/users_files/20420514/f73713a43039fd44a 9e595d01b9adf7a.pdf

3. Меморандум безперервного процесу освіти Європейського Союзу (2006). Адукатар № 2 (8), С. 25. Режим доступу: http://adukatar.net/wpcontent/uploads/2009/12/Adu_8_Pages_24-27.pdf

4. Manifesto for Adult Learning in the 21st Century: European Association for the Education of Adults [Електронний pecypc]. - Режим доступу: http://www.eaea.org/media/policyadvocacy/manifesto/manifesto.pdf

\section{References:}

1. Pro zatverdzhennja profesijnogo standartu «Praktichnij psiholog zakladu osviti» : Nakaz Ministerstva ekonomiki Ukraïni vid 24.11.2020 № 2425 [On approval of the professional standard "Practical psychologist of an educational institution": Order of the Ministry of Economy of Ukraine dated 24.11.2020 № 2425] Retrieved from: https://mon.gov.ua/ua/news/zatverdzhenoprofesijnij-standart-praktichnij-psiholog-zakladu-osviti [in Ukrainian]

2. Pro zatverdzhennja profesijnogo standartu za profesijami "Vchitel' pochatkovih klasiv zakladu zagal'noï seredn'oï osviti", "Vchitel' zakladu zagal'noï seredn'oï osviti","Vchitel' z pochatkovoï osviti (z diplomom molodshogo specialista)" : Nakaz Ministerstva rozvitku ekonomiki, torgivli ta sil's'kogo gospodarstva vid 23.12.2020 r. №2736 [On approval of the professional standard for the professions "Primary school teacher of general secondary education", "Teacher of general secondary education", "Primary education teacher (with a diploma of junior specialist)": Order of the Ministry of Economy, Trade and Agriculture of 23.12 .2020 №2736] Retrieved from: https://rada.info/upload/users_ files/20420514/f73713a43039fd44a9e595d01b9adf7a.pdf [in Ukrainian]

3. Memorandum bezperervnogo procesu osviti Evropejs'kogo Sojuzu (2006). Adukatar № 2 (8), S. 25. Retrieved from: http://adukatar.net/wpcontent/uploads/ 2009/12/Adu_8_Pages_24-27.pdf [in Russian]

4. Manifesto for Adult Learning in the 21st Century: European Association for the Education of Adults. Retrieved from: http://www.eaea.org/media/policy-advocacy/manifesto/manifesto.pdf 